\title{
Chemical composition, antioxidant properties and hepatoprotective effects of chamomile (Matricaria recutita L.) decoction extract against alcohol-induced oxidative stress in rat
}

\author{
Hichem Sebai ${ }^{1,2}$, Mohamed-Amine Jabri ${ }^{1,2}$, Abdelaziz Souli $^{2}$, Karim Hosni $^{3}$, Kais Rtibi $^{2}$, \\ Olfa Tebourbi ${ }^{1}$, Jamel El-Benna ${ }^{4}$ and Mohsen Sakly ${ }^{1}$ \\ 1 Laboratoire de Physiologie Intégrée, Département des Sciences de la Vie, Faculté des Sciences de Bizerte, 7021 Zarzouna, Tunisia \\ 2 Laboratoire de Nutrition et Physiologie Animale, Institut Supérieur de Biotechnologie de Béja, Avenue Habib Bourguiba, \\ B.P. 382, 9000 Béja, Tunisia \\ 3 Laboratoire des Substances Naturelles, Institut National de Recherche et d'Analyse Physico-chimique, Sidi Thabet, \\ 2020 Ariana, Tunisia \\ 4 INSERM, U1149, Centre de Recherche Sur l'Inflammation, Faculté de Médecine X. Bichat 75018 Paris, France
}

\begin{abstract}
The present study assessed the chemical composition, antioxidant properties, and hepatoprotective effects of subacute pre-treatment with chamomile (Matricaria recutita L.) decoction extract $(\mathrm{CDE})$ against ethanol $(\mathrm{EtOH})$-induced oxidative stress in rats. The colorimetric analysis demonstrated that the CDE is rich in total polyphenols, total flavonoids and condensed tannins, and exhibited an important in vitro antioxidant activity. The use of LC/MS technique allowed us to identify 10 phenolic compounds in CDE. We found that CDE pretreatment, in vivo, protected against $\mathrm{EtOH}$-induced liver injury evident by plasma transaminases activity and preservation of the hepatic tissue structure. The CDE counteracted EtOH-induced liver lipoperoxidation, preserved thiol -SH groups and prevented the depletion of antioxidant enzyme activity of superoxide dismutase (SOD), catalase (CAT) and glutathione peroxidase (GPx). We also showed that acute alcohol administration increased tissue and plasma hydrogen peroxide $\left(\mathrm{H}_{2} \mathrm{O}_{2}\right)$, calcium and free iron levels. More importantly, CDE pre-treatment reversed all EtOH-induced disturbances in intracellular mediators. In conclusion, our data suggest that $\mathrm{CDE}$ exerted a potential hepatoprotective effect against EtOH-induced oxidative stress in rat, at least in part, by negatively regulating Fenton reaction components such as $\mathrm{H}_{2} \mathrm{O}_{2}$ and free iron, which are known to lead to cytotoxicity mediated by intracellular calcium deregulation.
\end{abstract}

Key words: Chamomile - Ethanol — Liver - Oxidative stress - Rat

\begin{abstract}
Abbreviations: ALD, alcoholic liver disease; ALT, alanine aminotransferase; AST, aspartate aminotransferase; CAT, catalase; CDE, chamomile decoction extract; DW, dry weight; EtOH, ethanol; $\mathrm{GPx}$, glutathione peroxidase; $\mathrm{H}_{2} \mathrm{O}_{2}$, hydrogen peroxide; MDA, malondialdehyde; ROS, reactive oxygen species; SOD, superoxide dismutase; TCA, trichloroacetic acid.
\end{abstract}

\section{Introduction}

Chamomile (Matricaria recutita L.) is one of the most widely used and well-documented medicinal plants in the

Correspondence to: Hichem Sebai, Laboratoire de Physiologie Intégrée, Département des Sciences de la Vie, Faculté des Sciences de Bizerte, 7021 Zarzouna, Tunisia

E-mail: sebaihichem@yahoo.fr world (Salamon 1992). It has been included for centuries in the pharmacopoeia of several countries including Tunisia. The phytochemical screening of this plant revealed that it is rich in cytoprotective active molecules such as phenolic compounds (McKay and Blumberg 2006). Therefore, owing mainly to their antioxidant (Hernández-Ceruelos et al. 2010) and anti-inflammatory (Bulgari et al. 2012) properties, chamomile extract, or its essential oils are known to exhibit neuro-protective (Ranpariya et al. 2011), anti-allergic (Chan- 
drashekhar et al. 2011), anti-microbial (Silva et al. 2012) and anticancer (Matić et al. 2013) activities.

Alcoholic liver diseases (ALD) remain the principal cause of death in both the advanced and developing countries of the world (Maddrey 2000). They are associated with onethird of all traumatic injury deaths per year (Li et al. 1997; Rehm et al. 2003). The administration of ethanol generates reactive oxygen species (ROS), including superoxide anion, hydroxyl radical and hydrogen peroxide (Nordmann 1994; Albano 2008). However, the accumulation of ROS causes lipid peroxidation and the depletion of endogenous antioxidant enzyme activities, such as SOD, CAT, and GPx, which contribute to the pathogenesis of ALD (Samuhasaneeto et al. 2009). Several investigations have been conducted to counteract the liver diseases induced by oxidative challenges during alcohol consumption by reinforcing the endogenous antioxidant defense system (Ozaras et al. 2003; Souli et al. 2013).

Accordingly, the present study was designed to evaluate the putative hepatoprotective role of chamomile (Matricaria recutita $\mathrm{L}$.) decoction extract (CDE) (10 days) against oxidative stress induced by acute ethanol exposure and the mechanism involved in such protection.

\section{Materials and Methods}

\section{Chemicals}

Epinephrine, bovine catalase, 2-thio-barbituric acid (TBA) and butylated hydroxytoluene (BHT) were purchased from Sigma Chemicals Co. (Germany). All other chemicals used were of analytical reagent grade.

\section{Preparation of chamomile decoction extract}

Chamomile flowers were collected from the region of Beja (North-West of Tunisia) during March 2013. The chamomile decoction extract was prepared as previously described by Sebai et al. (2014). Briefly, the plant material was later dried in an incubator at $50^{\circ} \mathrm{C}$ during $72 \mathrm{~h}$ and powdered in an electric blender (Moulinex Ovatio 2, FR). The decoction was made with double distilled water $(1 / 5 ; \mathrm{w} / \mathrm{v})$ at $100^{\circ} \mathrm{C}$ during five minutes under magnetic agitation and the homogenate was filtered through a colander ( $0.5 \mathrm{~mm}$ mesh size). Finally, the obtained extract $(\mathrm{CDE})$ was stored at $-80^{\circ} \mathrm{C}$ until used.

\section{Animals and treatment}

Healthy adult male Wistar rats (200-220 g body weight, 15 weeks old) were purchased from the Pasteur Institute of Tunis and used in accordance with the local ethics committee of Tunis University for the use and care of animals in accordance with the NIH recommendations. They were provided with standard food (standard pellet diet- Badr Utique-TN) and water ad libitum and maintained in animal house at controlled temperature $\left(22 \pm 2^{\circ} \mathrm{C}\right)$ with a $12 \mathrm{~h}$ light-dark cycle. The rats were divided into half a dozen groups of 10 animals each. Groups 1 and 3 served as controls and had a physiological solution $(\mathrm{NaCl}, 0.9 \%$, p.o.). Group 2 received CDE ( $50 \mathrm{mg} / \mathrm{kg}$, b.w., p.o.). Groups 4,5 , and 6 were pre-treated with various doses of $\operatorname{CDE}(25$, 50 , and $100 \mathrm{mg} / \mathrm{kg}$, b.w. p.o.). Animals were pre-treated for 10 days. Sixty minutes after the administration of the last dose of $\mathrm{CDE}$, all the animals, except those belonging to the groups 1 and 2, were acutely per orally intoxicated by $\mathrm{EtOH}$ $(6 \mathrm{~g} / \mathrm{kg}, b . w$.$) . Two hours later, animals were sacrificed; their$ livers were rapidly excised and homogenized in phosphate buffer saline. After centrifugation at $10000 \times g$ for $10 \mathrm{~min}$ at $4^{\circ} \mathrm{C}$, supernatant was used for biochemical determination of protein, free iron, calcium, $\mathrm{H}_{2} \mathrm{O}_{2}$, $-\mathrm{SH}$ groups and MDA levels as well as antioxidant enzyme activities. On the other hand, blood was likewise collected in heparinized tubes. After centrifugation at $3000 \times g$ during $15 \mathrm{~min}$, plasma was treated for free iron, $\mathrm{H}_{2} \mathrm{O}_{2}$, calcium and transaminase determinations.

\section{Total phenolic content}

Total phenolic content was determined by the colorimetric Folin-Cieucalteu method (Haseeb et al. 2006). Briefly, $500 \mu \mathrm{l}$ of the extract was added to $10 \mathrm{ml}$ of water and $0.5 \mathrm{ml}$ of Folin-Cieucalteu reagent. After $5 \mathrm{~min}, 8 \mathrm{ml}$ of $7.5 \%$ sodium carbonate solution was added. The reaction mixture was kept in the dark for $2 \mathrm{~h}$ and its optical density was measured at $765 \mathrm{~nm}$ using a UV-visible spectrophotometer (Beckman DU 640B). Gallic acid was applied as standard, and results were expressed as $\mathrm{mg}$ of gallic acid equivalents (mg GAE/g of dry weight (DW)).

\section{Total flavonoids determination}

Total flavonoid content was determined by the $\mathrm{AlCl}_{3}$ colorimetric method (Djeridane et al. 2006). Briefly, $1 \mathrm{ml}$ of the sample was mixed with $1 \mathrm{ml}$ of $2 \%$ aluminium chloride solution. After incubation for $15 \mathrm{~min}$ at room temperature, the optical density of the reaction mixture was evaluated at $430 \mathrm{~nm}$. Quercetin was used as a citation standard and the total flavonoid content was expressed as $\mathrm{mg}$ of quercetin equivalent (mg QtE/g DW).

\section{Condensed tannin determination}

The content of condensed tannins in CDE was determined utilizing the modified vanillin assay (Price et al. 1978). Briefly, $250 \mu \mathrm{l}$ of the sample was added to $750 \mu \mathrm{l}$ of water, 
$1.5 \mathrm{ml}$ of vanillin solution (4\%) and $750 \mu \mathrm{l}$ of $\mathrm{HCl} 12 \mathrm{~N}$. The reaction mixture was kept in the dark for $20 \mathrm{~min}$, and its optical density was measured at $500 \mathrm{~nm}$. Catechin was used as standard, and the results were expressed as mg of catechin equivalents (mg CtE/g DW).

\section{HPLC-PDA-MS analysis}

The chromatographic separation and mass spectrometric analyses of phenolics contained in the aqueous extracts were carried out on an Agilent 1100 series HPLC systems equipped with a photodiode array detector (PDA) and a triple quadrupole mass spectrometer type Micromass Autospec Ultima Pt (Kelso, UK) interfaced with an ESI ion source. Separation was achieved using a Superspher ${ }^{\circledR} 100$ (12.5 cm $\times 2$ mm i.d., $4 \mu \mathrm{m}$, Agilent Technologies, Rising Sun, $\mathrm{MD})$ at $45^{\circ} \mathrm{C}$. The samples $(20 \mu \mathrm{l})$ were eluted through the column with a gradient mobile phase consisting of A $(0.1 \%$ acetic acid) and $B$ (acetonitrile) with a flow rate of $0.25 \mathrm{ml} / \mathrm{min}$. The following multi-step linear solvent gradient was employed: $0-5 \mathrm{~min}, 2 \% \mathrm{~B}, 5-75 \mathrm{~min}, 88 \% \mathrm{~B}$, 75-90 $\mathrm{min}, 2 \% \mathrm{~B}$.

The detection of PDA was performed in the 200-400 nm wavelength range and the mass spectra were recorded in negative ion mode, under the following operating conditions: capillary voltage, $3.2 \mathrm{kV}$; cone voltage, $115 \mathrm{~V}$; probe temperature, $350^{\circ} \mathrm{C}$; ion source temperature, $110^{\circ} \mathrm{C}$. The spectra were acquired in the $\mathrm{m} / \mathrm{z}$ range of $150-750 \mathrm{amu}$.

The identification of phenolic compounds was based on co-chromatography with authentic standards, when available. PDA spectra and mass spectra were used to affirm the identity of compounds previously reported in the literature (Clifford et al. 2007; Lai et al. 2007; Lin and Harnly 2010; Parveen et al. 2011).

\section{Free radical-scavenging activity on $D P P H$}

The antioxidant capacity of CDE was performed using 2,2-diphenyl-1-picrylhydrazyl (DPPH) radical-scavenging activity as previously described by Grzegorczyk et al. (2007). Briefly, various concentrations of $\operatorname{CDE}(20,50,100,150$, and $200 \mu \mathrm{g} / \mathrm{ml}$ ) were added to $1 \mathrm{ml}$ of $0.1 \mathrm{~mm}$ methanol solution of DPPH and incubated at $27^{\circ} \mathrm{C}$ during $30 \mathrm{~min}$. The optical density of the sample was quantified at $517 \mathrm{~nm}$. DPPH radical-scavenging activity (RSA), expressed as a percentage, was estimated utilizing the following formula:

$$
\operatorname{RSA}(\%)=\frac{A_{\mathrm{DPPH}}-\left(A_{\text {sample }}-A_{\text {control }}\right)}{A_{\mathrm{DPPH}}} \times 100
$$

Ascorbic acid was used as a reference molecule in the same concentration as the test extract.
All the analyses were executed in triplicate. The efficacy concentration 50 (EC50) value was determined as the concentration (in $\mu \mathrm{g} / \mathrm{ml}$ ) of the compound required to scavenge $50 \%$ of the DPPH radical.

\section{Lipid peroxidation measurement}

Liver lipid peroxidation was determined by MDA measurement according to the double heating method (Draper and Hadley 1990). Briefly, aliquots from liver tissue homogenates were mixed with BHT-trichloroacetic acid (TCA) solution containing $1 \%$ BHT $(\mathrm{w} / \mathrm{v})$ dissolved in $20 \%$ TCA $(\mathrm{w} / \mathrm{v})$ and centrifuged at $1000 \times g$ for $5 \mathrm{~min}$ at $4^{\circ} \mathrm{C}$. Supernatant was blended with solution containing $(0.5 \mathrm{~N} \mathrm{HCl}, 120 \mathrm{mM}$ TBA buffered in $26 \mathrm{mM}$ Tris) and then heated at $80^{\circ} \mathrm{C}$ for $10 \mathrm{~min}$. After cooling, the absorbance of the resulting chromophore was determined at $532 \mathrm{~nm}$. MDA levels were determined by using an extinction coefficient for MDA-TBA complex of $1.56 \times 10^{5} \mathrm{M}^{-1} \cdot \mathrm{cm}^{-1}$.

\section{Thiol group measurement}

The total concentration of thiol groups (-SH) was performed according to Ellman's method (Ellman 1959). Briefly, aliquots from liver tissue were mixed with $100 \mu \mathrm{l}$ of $10 \%$ SDS and $800 \mu \mathrm{l}$ of $10 \mathrm{mM}$ phosphate buffer ( $\mathrm{pH} 8)$, and the optical density was measured at $412 \mathrm{~nm}\left(\mathrm{~A}_{0}\right)$. After adding $100 \mu \mathrm{l}$ of 5,5'-dithiobis-(2-nitrobenzoic acid) (DTNB), the reaction mixture was incubated at $37^{\circ} \mathrm{C}$ during $60 \mathrm{~min}$ and a new value $\left(A_{1}\right)$ was determined. The thiol groups concentration was calculated from $A_{1}$ to $A_{0}$ subtraction using a molar extinction coefficient of $13.6 \times 10^{3} \mathrm{M}^{-1} \cdot \mathrm{cm}^{-1}$. The results were expressed as nmol of thiol groups per $\mathrm{mg}$ of protein.

\section{Antioxidant enzyme activity assays}

The activity of SOD was determined using modified epinephrine assays (Misra and Fridovich 1972). At alkaline $\mathrm{pH}$, superoxide anion $\mathrm{O}_{2}{ }^{-}$causes the autoxidation of epinephrine to adenochrome; while competing with this reaction, SOD decreased the adenochrome formation. One unit of SOD is defined as the amount of the extract that inhibits the rate of adenochrome formation by $50 \%$. Enzyme extract was added in $2 \mathrm{ml}$ reaction mixture containing $10 \mu \mathrm{l}$ of bovine catalase $(0.4 \mathrm{U} / \mu \mathrm{l}), 20 \mu \mathrm{l}$ epinephrine $(5 \mathrm{mg} / \mathrm{ml})$ and $62.5 \mathrm{mM}$ sodium carbonate/bicarbonate buffer $\mathrm{pH}$ 10.2. Changes in absorbance were recorded at $480 \mathrm{~nm}$.

The activity of CAT was assessed by measuring the initial rate of $\mathrm{H}_{2} \mathrm{O}_{2}$ disappearance at $240 \mathrm{~nm}$ (Aebi 1984). The reaction mixture contained $33 \mathrm{mM} \mathrm{H}_{2} \mathrm{O}_{2}$ in $50 \mathrm{mM}$ phosphate buffer $\mathrm{pH} 7.0$ and the activity of CAT was calculated using the extinction coefficient of $40 \mathrm{mM} M^{-1} \cdot \mathrm{cm}^{-1}$ for $\mathrm{H}_{2} \mathrm{O}_{2}$. 
The activity of GPx was quantified by the procedure of Flohé and Günzler (1984). Briefly, $1 \mathrm{ml}$ of reaction mixture containing $0.2 \mathrm{ml}$ of liver supernatant, $0.2 \mathrm{ml}$ of phosphate buffer $0.1 \mathrm{M}$ (pH 7.4), $0.2 \mathrm{ml}$ of GSH (4 mM) and $0.4 \mathrm{ml}$ of $\mathrm{H}_{2} \mathrm{O}_{2}(5 \mathrm{mM})$ was incubated at $37^{\circ} \mathrm{C}$ for $1 \mathrm{~min}$ and the reaction was stopped by the addition of $0.5 \mathrm{ml} \mathrm{TCA}(5 \%, \mathrm{w} / \mathrm{v})$. After centrifugation at $1500 \times g$ for $5 \mathrm{~min}$, aliquot $(0.2 \mathrm{ml})$ of supernatant was combined with $0.5 \mathrm{ml}$ of phosphate buffer $0.1 \mathrm{M} \mathrm{pH} 7.4$ and $0.5 \mathrm{ml}$ DTNB $(10 \mathrm{mM})$ and reading at $412 \mathrm{~nm}$. The activity of GPx was expressed as nmol of GSH consumed $/ \mathrm{min} / \mathrm{mg}$ protein.

\section{Assessment of liver function}

Plasma aspartate aminotransferase (AST) and alanine aminotransferase (ALT) were measured using commercially available diagnostic kits supplied by Randox laboratories (Ardmore, Northern Ireland, UK).

\section{$\mathrm{H}_{2} \mathrm{O}_{2}$ determination}

The tissue and plasma $\mathrm{H}_{2} \mathrm{O}_{2}$ levels were performed according to Dingeon et al. (1975). Briefly, the hydrogen peroxide reacts with $\mathrm{p}$-hydroxybenzoic acid and 4-aminoantipyrine in the presence of peroxidase leading to the formation of quinoneimine that has a pink color detected at $505 \mathrm{~nm}$.

\section{Iron measurement}

Tissue and plasma non haem iron were measured colorimetrically using ferrozine as described by Leardi et al. (1998). Briefly, a solution of guanidine acetate was firstly used to dissociate iron from transferrin-iron complex. After its reduction by adding ascorbic acid, the labile iron reacts with ferrozine leading to the formation of pink complex measured at $562 \mathrm{~nm}$.

\section{Calcium determination}

Tissue and plasma calcium were performed using a colorimetric method according to Stern and Lewis (1957). Briefly, at alkaline medium, calcium reacted with cresolphtalein leading to colored complex measurable at $570 \mathrm{~nm}$.

\section{Protein determination}

Protein concentration was measured according to Hartree (1972) which is a slight change of the Lowry method. Serum albumin was used as standard.

\section{Statistical analysis}

The data were analyzed by one-way analysis of variance (ANOVA) and were expressed as means \pm standard error of the mean (S.E.M.). The data are representative of 10 independent experiments. All statistical tests were two-tailed, and a $p$ value of 0.05 or less was considered significant.

\section{Results}

\section{Total phenolics, flavonoids, and condensed tannins}

As shown in Table 1, the CDE (extraction yield, 5\%) exhibited high levels of total phenolics (37.12 mg GAE/g DW), total flavonoids (24.83 mg QtE/g DW) and condensed tannins (1.74 mg CtE/g DW).

\section{Characterisation of phenolic compounds of CDE by LC/MS analysis}

The phenolic profile of CDE is shown in Figure 1. The identified compounds are presented in Table 2 . Ten phenolic compounds were characterized and 7 (peaks 1-7) of them were unambiguously identified by comparing their retention time, UV and mass spectra with those of reference standards. They were gallic acid (peak $1 ; \mathrm{Rt}=4.2 \mathrm{~min} ;[\mathrm{M}-\mathrm{H}]^{-}=169$ ), protocatechuic acid (peak 2; Rt $=7.7 \mathrm{~min} ;[\mathrm{M}-\mathrm{H}]^{-}=153$ ), chlorogenic acid (peak 3; Rt = $16.7 \mathrm{~min} ;[\mathrm{M}-\mathrm{H}]^{-}=353$ ), cafeic acid (peak 4; Rt $=17.6 \mathrm{~min} ;[\mathrm{M}-\mathrm{H}]^{-}=179$ ), cafeoylquinic acid (peak 5; Rt $=20.18 \mathrm{~min} ;[\mathrm{M}-\mathrm{H}]^{-}=353$ ), salicylic acid (peak 6; Rt = $21.2 \mathrm{~min} ;[\mathrm{M}-\mathrm{H}]^{-}=137$ ) and quercetin (peak 7; Rt = $30.05 \mathrm{~min} ;[\mathrm{M}-\mathrm{H}]^{-}=301$ ).

The remaining components (peaks 8-10) were provisionally identified based on the analysis of their UV, mass spectra, and comparison with literature (Clifford et

Table 1. EC50 values of DPPH radical-scavenging activity and contents of total polyphenols, total flavonoids and condensed tannins in chamomile decoction extract (CDE)

\begin{tabular}{lcccc}
\hline & $\begin{array}{c}\text { Total polyphenols } \\
(\mathrm{mg} \mathrm{GAE} / \mathrm{g} D W)\end{array}$ & $\begin{array}{c}\text { Total flavonoids } \\
(\mathrm{mg} \mathrm{QtE} / \mathrm{g} \text { DW })\end{array}$ & $\begin{array}{c}\text { Condensed tannins } \\
(\mathrm{mg} \mathrm{CtE} / \mathrm{g} \mathrm{DW})\end{array}$ & $\begin{array}{c}\text { EC50 of DPPH radical-scavenging } \\
\text { activity }(\mu \mathrm{g} / \mathrm{ml})\end{array}$ \\
\hline $\mathrm{CDE}$ & $37.12 \pm 3.24$ & $24.83 \pm 2.78$ & $1.74 \pm 0.25$ & $165 \pm 2.3$ \\
Ascorbic acid & - & - & - & $147 \pm 0.9$ \\
\hline
\end{tabular}

GAE, gallic acid equivalent; QtE, quercetin equivalent; CtE, catechin equivalent; EC50, the effective concentration of sample that can decrease DPPH concentration by 50\%; DW, dry weight. 


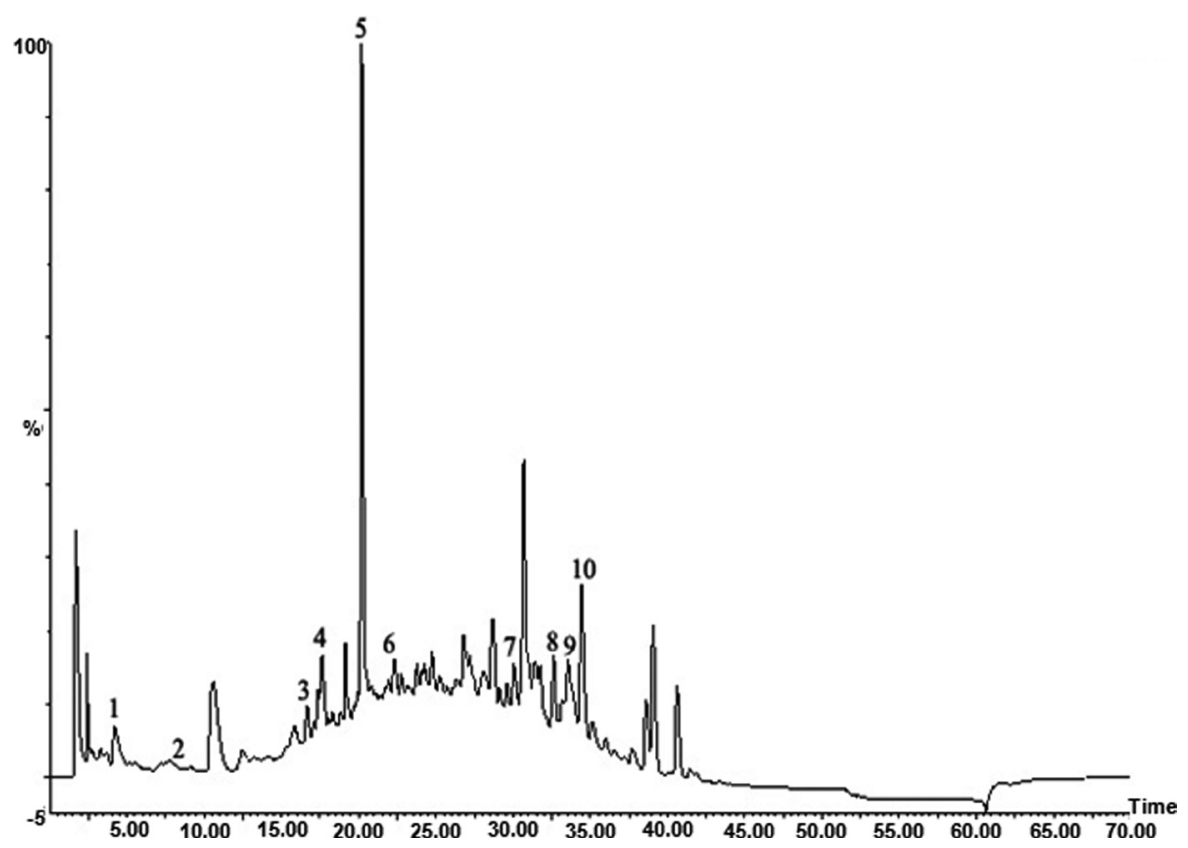

Figure 1. LCMS-TIC of phenolic components in the chamomile decoction, extract (assignment of peaks is given in Table 2).

al. 2007; Lai et al. 2007; Lin and Harnly 2010; Parveen et al. 2011). Accordingly, peak $8\left(\mathrm{Rt}=32.8 \mathrm{~min} ;[\mathrm{M}-\mathrm{H}]^{-}=\right.$ 391), peak $9\left(\mathrm{Rt}=33.56 \mathrm{~min} ;[\mathrm{M}-\mathrm{H}]^{-}=299\right)$ and peak 10 $\left(\mathrm{Rt}=34.43 \mathrm{~min} ;[\mathrm{M}-\mathrm{H}]^{-}=329\right)$ were tentatively identified as quinic acid derivative, hydroxybenzoic acid-Ohexoside and 5,7,4'-trihydroxy-6,3'-dimethoxyflavone, respectively.

\section{Antioxidant capacity of $C D E$}

Concerning the antioxidant capacity, we have found that the radical-scavenging activity of CDE and ascorbic acid against DPPH radical increased significantly in a dosedependent manner (Fig. 1). The EC50 values calculated from the graph (Fig. 2) demonstrated that the RSA of CDE
$(\mathrm{EC} 50=152.43 \mu \mathrm{g} / \mathrm{ml})$ appeared significantly higher than ascorbic acid $(\mathrm{EC} 50=87.57 \mu \mathrm{g} / \mathrm{ml})$ as well known reference molecule (Table 1).

\section{Assessment of liver injury}

The data from Figure 3 show that acute EtOH (6 g/kg b.w.) administration significantly increased the plasma AST and ALT activity used as an index of liver injury while CDE alone at $50 \mathrm{mg} / \mathrm{kg} ; b . w$. has no effect on both parameters. CDE $(25,50$ and $100 \mathrm{mg} / \mathrm{kg} ;$ b.w. $)$ pre-handling significantly and dose-dependently protected against liver injury caused by alcohol administration.

The histological study revealed minor microvesicular steatosis in the liver of rats treated with $\mathrm{EtOH}$ alone. $\mathrm{CDE}$

Table 2. Retention time (Rt), wavelength of maximum absorption ( $\lambda$ max $)$, deprotonated molecular mass $[\mathrm{M}-\mathrm{H}]^{-}$and tentative identification of the phenolic compounds in chamomile decoction extract

\begin{tabular}{ccccl}
\hline Peak & Rt $(\min )$ & $\lambda \max (\mathrm{nm})$ & {$[\mathrm{M}-\mathrm{H}]^{-}$} & Tentative identification \\
\hline 1 & 4.2 & 255 & 169 & Gallic acid \\
2 & 7.7 & 259,295 & 153 & Protocatechuic acid \\
3 & 16.7 & 325 & 353 & Chlorogenic acid \\
4 & 17.6 & 323 & 179 & Cafeic acid \\
5 & 20.18 & 328 & 353 & Cafeoylquinic acid \\
6 & 21.2 & 327 & 137 & Salicylic acid \\
7 & 30.05 & 255,369 & 301 & Quercetin \\
8 & 32.8 & 321 & 391 & Quinic acid derivative \\
9 & 33.56 & 267 & 299 & Hydroxybenzoic acid-O-hexoside \\
10 & 34.43 & 275,339 & 329 & $5,7,4^{\prime}$-Trihydroxy-6,3'-dimethoxyflavone \\
\hline
\end{tabular}


pre-treatment greatly reduced the histopathological changes induced by acute alcohol intoxication (Fig. 4).

\section{Liver lipoperoxidation}

Bearing on the effect of EtOH and CDE on oxidative stress condition, we firstly studied the liver lipoperoxidation (Fig. 5). EtOH per se drastically increased the liver MDA level. CDE pre-treatment significantly and dose dependently reversed lipoperoxidation induced by $\mathrm{EtOH}$ treatment, while CDE alone at $50 \mathrm{mg} / \mathrm{kg} ;$ b.w. had no effect on hepatic lipid peroxidation.

\section{Changes in tissue -SH groups}

We also examined the liver -SH groups level. Treatment with $\mathrm{EtOH}$ caused a considerable decrease in the content of -SH groups, which evidenced the induction of oxidative stress and significant thiol depletion during alcoholism. This effect was significantly and dose-dependently corrected by subacute CDE pre-treatment (Fig. 6).

\section{Liver antioxidant enzyme activities}

In the present study, the effects of EtOH and CDE treatment on hepatic antioxidant enzyme activities were investigated and the results are presented in Figure 7. As expected, acute EtOH treatment significantly decreased hepatic antioxidant enzyme activities as SOD (Fig. 7A), CAT (Fig. 7B), and GPx (Fig. 7C). CDE pre-treatment significantly reversed all EtOH-induced antioxidant enzymes depletion in a dose-dependent manner. More importantly, CDE alone significantly ameliorated SOD and CAT activities but not GPx.

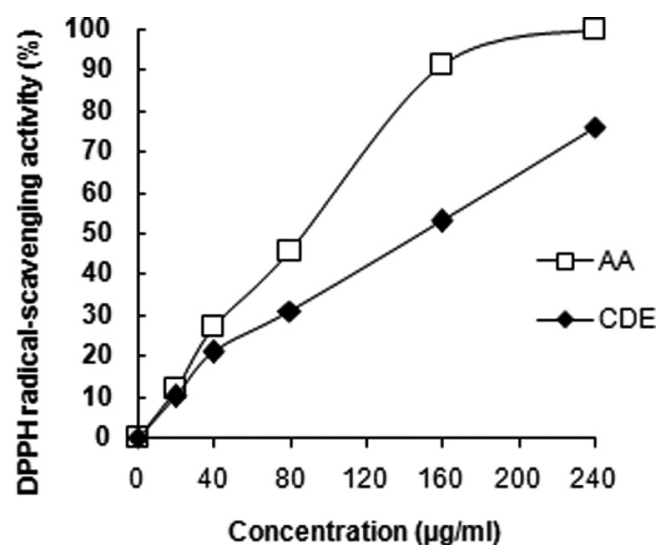

Figure 2. Free radical-scavenging activity of chamomile decoction, extract (CDE) and ascorbic acid (AA) on 2,2-diphenyl-1picrylhydrazyl (DPPH).
Tissue and plasma iron, $\mathrm{H}_{2} \mathrm{O}_{2}$ and calcium measurements

We further looked at the effect of ethanol and CDE on intracellular mediators as hydrogen peroxide (Fig. 8), free iron (Fig. 9) and calcium (Fig. 10) levels in plasma and hepatic tissue. As expected, alcohol treatment increased iron, $\mathrm{H}_{2} \mathrm{O}_{2}$ and calcium levels in plasma and liver. CDE pre-treatment significantly protected against EtOH-induced intracellular mediators disturbances in a dose-dependent manner. CDE alone had no considerable effects on these parameters.

\section{Discussion}

In the present work, we investigated the protective effects of $\mathrm{CDE}$ on $\mathrm{EtOH}$-induced oxidative stress in rat liver as well
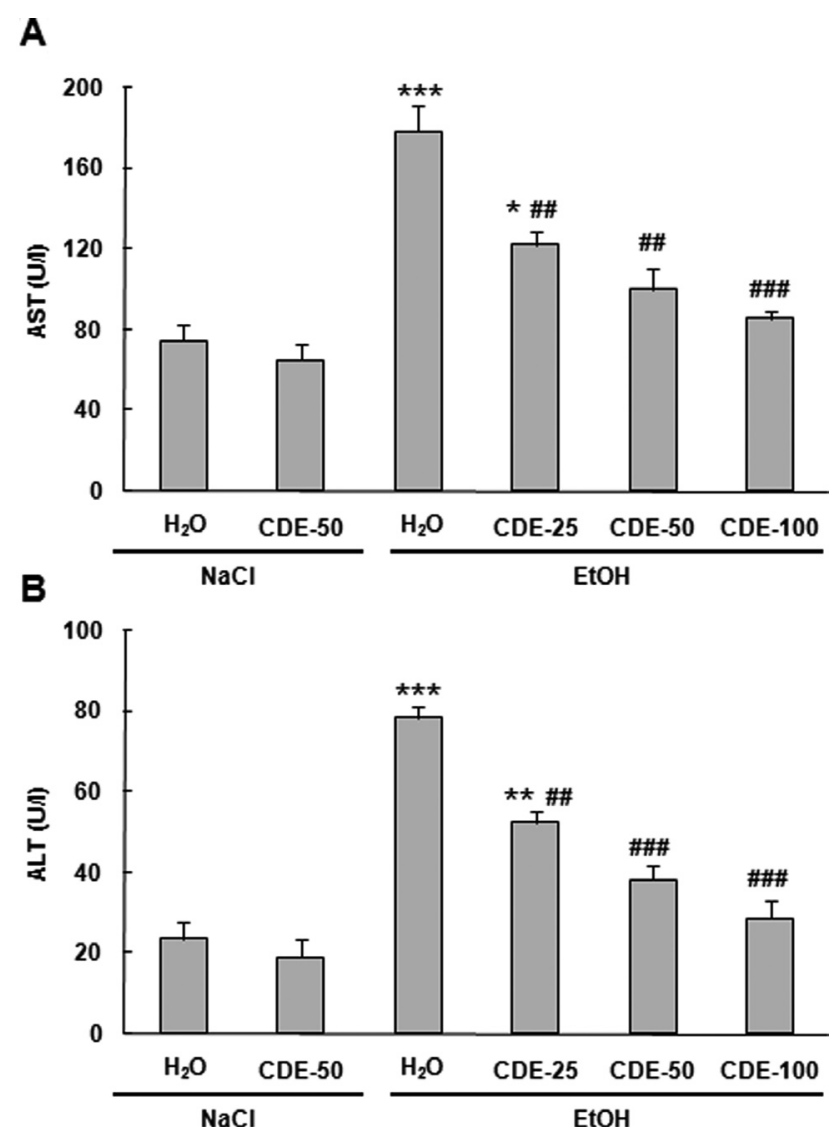

Figure 3. Subacute effect of chamomile decoction extract (CDE) on acute $\mathrm{EtOH}$-induced changes in plasma aspartate aminotransferase (AST, A) and alanine aminotransférase (ALT, B). Animals were pretreated during 10 days with $\operatorname{CDE}(25,50$ and $100 \mathrm{mg} / \mathrm{kg}$ b.w., p.o.) or vehicle (bidistilled $\mathrm{H}_{2} \mathrm{O}$ ), challenged with a single oral administration of $\mathrm{EtOH}(6 \mathrm{~g} / \mathrm{kg}$ b.w.) or $\mathrm{NaCl} 9 \%$ for 2 hours. Assays were carried out in triplicate $(n=10) .{ }^{*} p<0.05,{ }^{* *} \mathrm{p}<0.01,{ }^{* * *} p<0.001$ compared to control group; ${ }^{\# \#} p<0.01,{ }^{\# \# \#} p<0.001$ compared to EtOH group. 

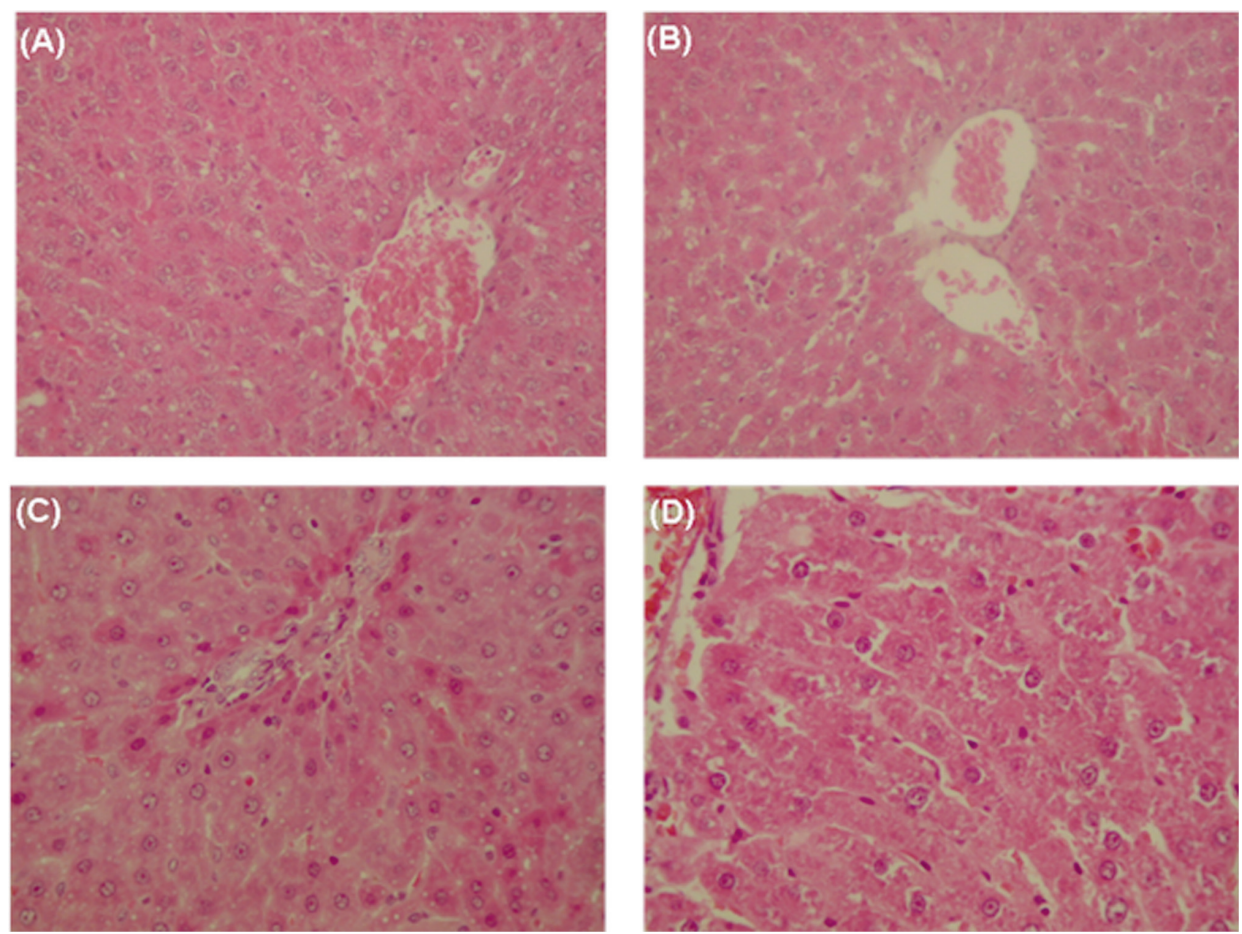

Figure 4. Liver histology showing the protective effect of $\mathrm{CDE}$ on $\mathrm{EtOH}$ induced hepatic injury in rats. Normal architecture in control (A) and CDE-treated animals (B). Minor microvesicular steatosis revealed by acute EtOH treatment (C) and protected by CDE pretreatment (D). CDE, chamomile decoction extract.

as characterized changes in intracellular mediators that may subserve such protection.

Our phytochemical study firstly revealed the presence of total polyphenols, total flavonoids, and condensed tannins

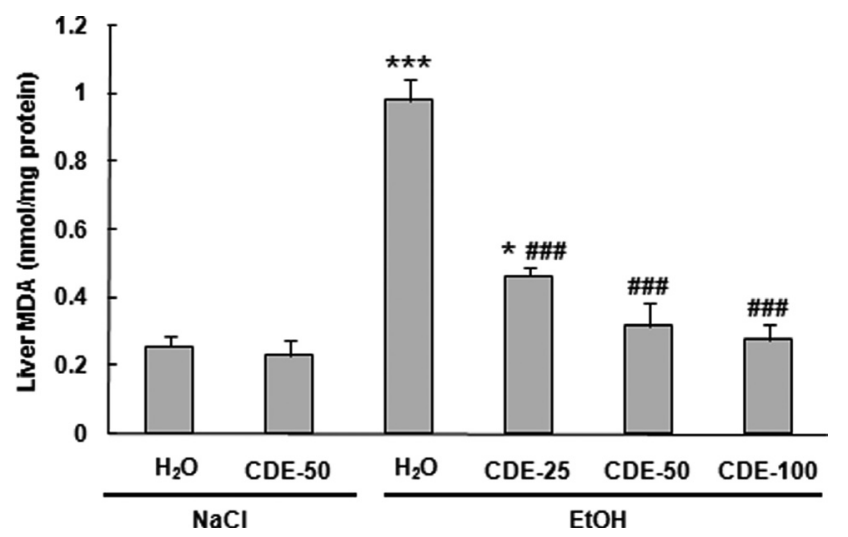

Figure 5. Subacute effect of $\mathrm{CDE}$ on acute EtOH-induced changes in liver MDA level. Animals were pre-treated during 10 days with $\mathrm{CDE}$ and intoxicated by a single oral administration of $\mathrm{EtOH}$ for 2 hours $(n=10) .{ }^{\star} p<0.05,{ }^{* * *} p<0.001$ compared to control group; $\#$ \#\# $p<0.001$ compared to EtOH group. CDE, chamomile decoction extract; MDA, malondialdehyde . in the CDE. The phenolic and flavonoids contents $(37.12 \pm$ $3.24 \mathrm{mg}$ EAG/g DW and $24.83 \pm 2.78 \mathrm{mg}$ EQt/g DW, respectively) appear higher than those of other medicinal plants such as Ceratonia siliqua pods extract known for its anti-

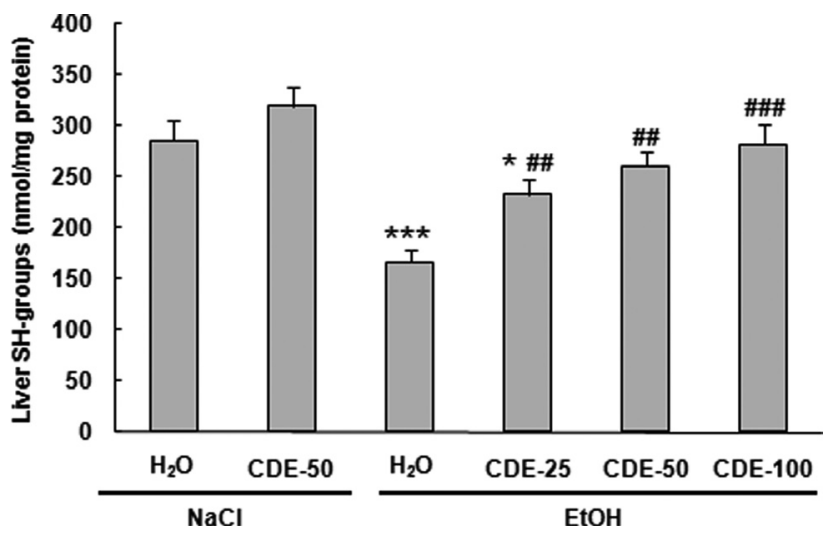

Figure 6. Subacute effect of $\mathrm{CDE}$ on acute EtOH-induced changes in liver -SH groups level. Animals were pre-treated during 10 days with $\mathrm{CDE}$ and intoxicated by a single oral administration of EtOH for 2 hours $(n=10)$. ${ }^{\star} p<0.05,{ }^{* * *} p<0.001$ compared to control group; ${ }^{\# \#} p<0.01,{ }^{\# \#} p<0.001$ compared to EtOH group. CDE, chamomile decoction extract. 
oxidant and hepato-protective properties (Sebai et al. 2013; Souli et al. 2013). CDE is richer in polyphenols and flavonoids but not condensed tannins when compared to infusion and
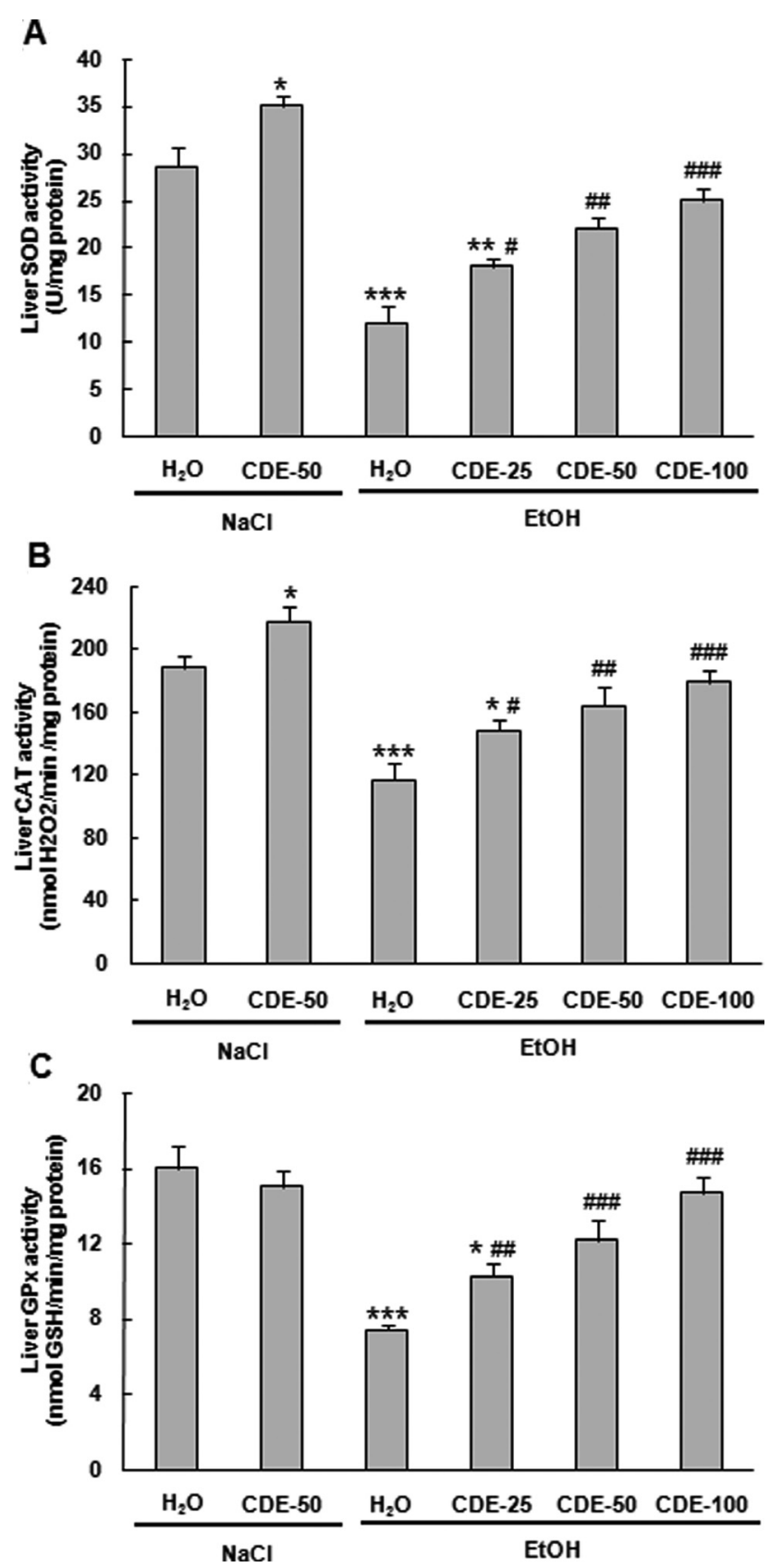

Figure 7. Subacute effect of $\mathrm{CDE}$ on acute EtOH-induced changes in liver antioxidant enzymes SOD (A), CAT (B) and GPx (C). Animals were pre-treated during 10 days with $\mathrm{CDE}$ and intoxicated by a single oral administration of EtOH for 2 hours $(n=10) .{ }^{*} p<$ $0.05,{ }^{* *} p<0.01,{ }^{* * *} p<0.001$ compared to control group; ${ }^{\#} p<$ $0.05,{ }^{\# \#} p<0.01,{ }^{\# \# \#} p<0.001$ compared to $\mathrm{EtOH}$ group. CDE, chamomile decoction extract; SOD, superoxide dismutase; CAT, catalase; GPx, glutathione peroxidase. maceration (data not shown). The use of HPLC-PDA-MS technique allowed us to identify gallic acid, protocatechuic acid, chlorogenic acid, cafeic acid, cafeoylquinic acid, salicylic acid, quercetin, quinic acid derivative, hydroxybenzoic acidO-hexoside, 5,7,4'-trihydroxy-6,3'-dimethoxyflavone. Our results generally corroborate previous reports with some discrepancies (Guimarães et al. 2013). However, the variability in chemical composition as well as phenolic compounds content can be attributed to the climatic conditions and the mode of extraction (Papagiannopoulos et al. 2004). Indeed, this variability may also be due to the variety of chamomile as recently described (Sharafzadeh and Alizadeh 2011).

On the other hand, using the DPPH radical-scavenging assay, we found that $\mathrm{CDE}$ presents a high scavenging

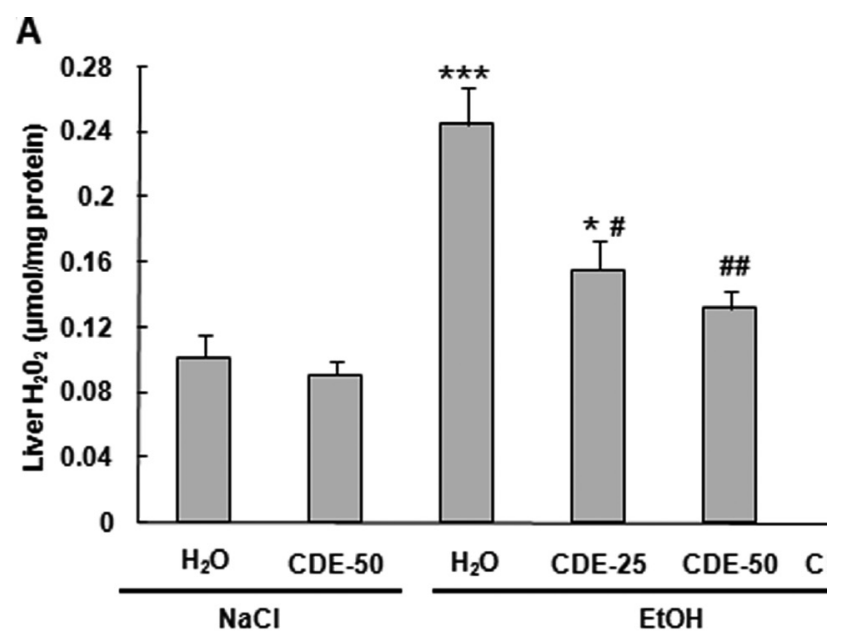

B

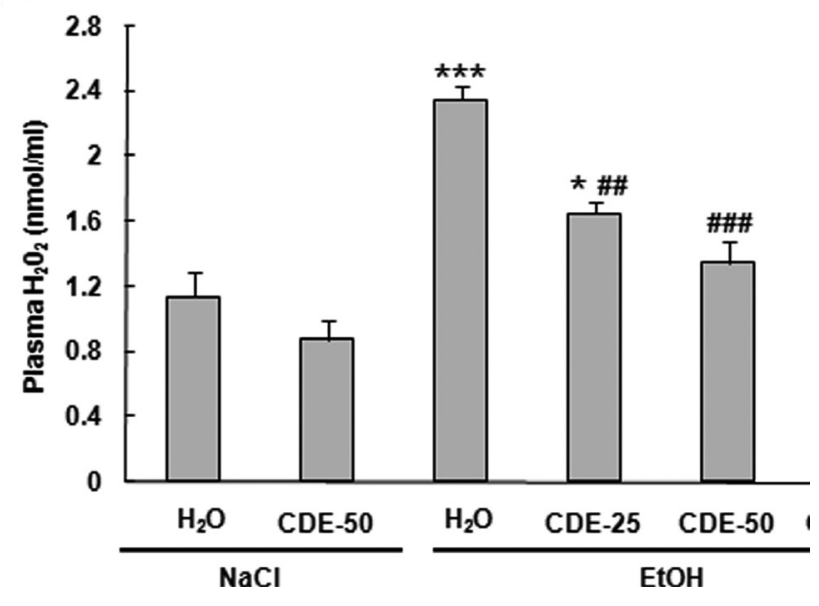

Figure 8. Subacute effect of $\mathrm{CDE}$ on acute $\mathrm{EtOH}$-induced changes in liver (A) and plasma (B) hydrogen peroxide level. Animals were pre-treated during 10 days with CDE and intoxicated by a single oral administration of EtOH for 2 hours $(n=10) .{ }^{\star} p<0.05,{ }^{* *} p<$ 0.001 compared to control group; ${ }^{\#} p<0.05,{ }^{\# \#} p<0.01,{ }^{\# \#} p<0.001$ compared to EtOH group. $\mathrm{CDE}$, chamomile decoction extract. 
capacity, albeit lesser than ascorbic acid which was used as a reference molecule. The antioxidant capacity of CDE is mainly related to the higher levels of polyphenols and flavonoids molecules (Guimarães et al. 2013). However, a positive correlation between phenolic compounds and antioxidant capacity is common in the majority of natural extracts (Chon et al. 2009; Hamad et al. 2010).

In vivo, we showed that alcohol administration provoked a clear hepatotoxicity as evidenced by an increase in plasma transaminases (ALT and AST) activity, used as indexes of liver injury. Chamomile pre-treatment significantly reversed EtOH-induced liver toxicity in a dose-dependent manner. The induction of ALT and AST activity following acute alcohol intoxication has been well documented (for review, see Ceccanti et al. 2006). However, it is very important to note that any observed increase in the plasma of these enzymes necessarily results from hepatocyte damage leading their release into extracellular space (Owumi et al. 2012). Thus, we can suggest that chamomile extract might prevent the activation of phagocytic Kupffer cells by decreasing the formation of inflammatory and fibrogenic mediators, as seen with Camellia sinenesis (Zhong et al. 2003). The histological analyses revealed only microvesicular lipid droplets in the livers of ethanol-treated rats. Our results are in line with the previous findings (Zhou et al. 2003; Donohue et al. 2012). However, other reports (Yang et al. 2012; Souli et al. 2013) demonstrated that acute alcohol intoxication induced a more marked structural changes. These discrepancies may result from the variations in experimental species, doses and protocols of ethanol administration.

EtOH-induced hepatotoxicity was also assessed by an increase in lipoperoxidation, decrease in - $\mathrm{SH}$ groups as well as depletion of antioxidant enzyme activities such as SOD, CAT and GPx. Alcohol consumption can lead to
A

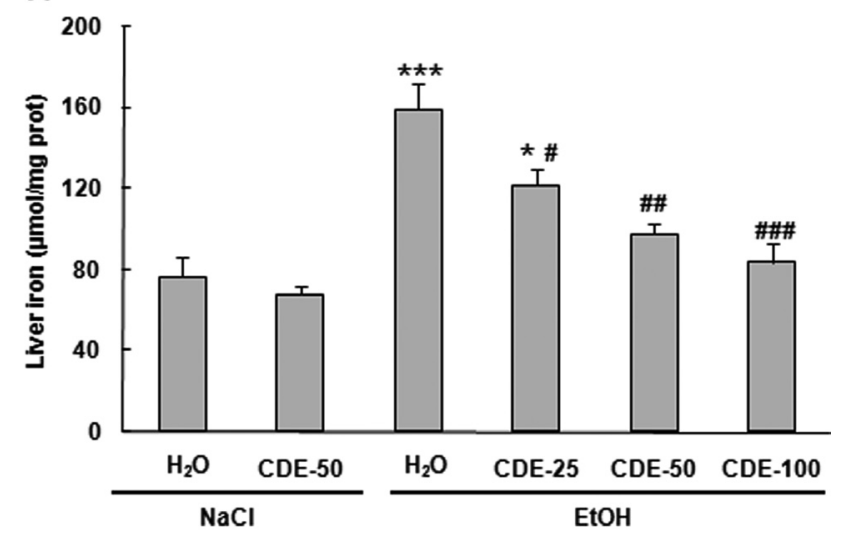

B

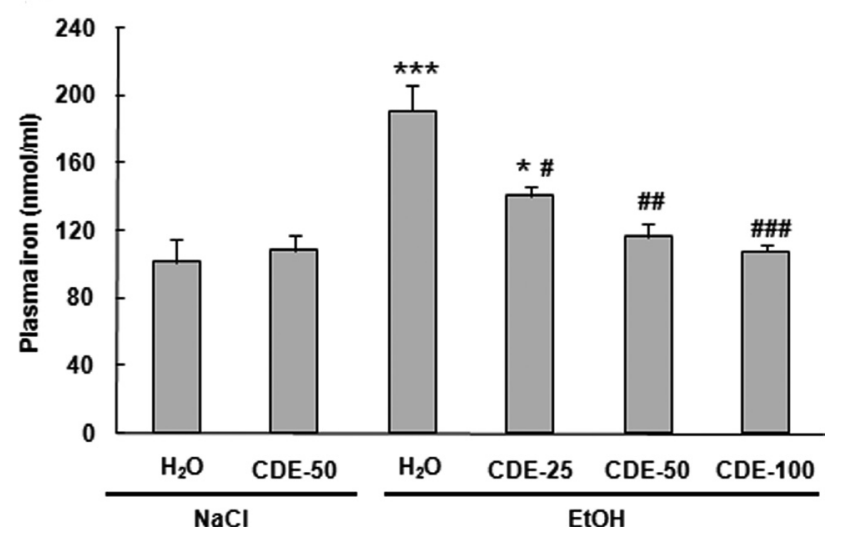

Figure 9. Subacute effect of $\mathrm{CDE}$ on acute EtOH-induced changes in liver (A) and plasma (B) free iron level. Animals were pre-treated during 10 days with $\mathrm{CDE}$ and intoxicated by a single oral administration of EtOH for 2 hours $(n=10) .{ }^{*} p<0.05,{ }^{* * *} p<0.001$ compared to control group; ${ }^{\#} p<0.05,{ }^{\#} p<0.01,{ }^{\# \#} p<0.001$ compared to EtOH group $\mathrm{CDE}$, chamomile decoction extract.
A

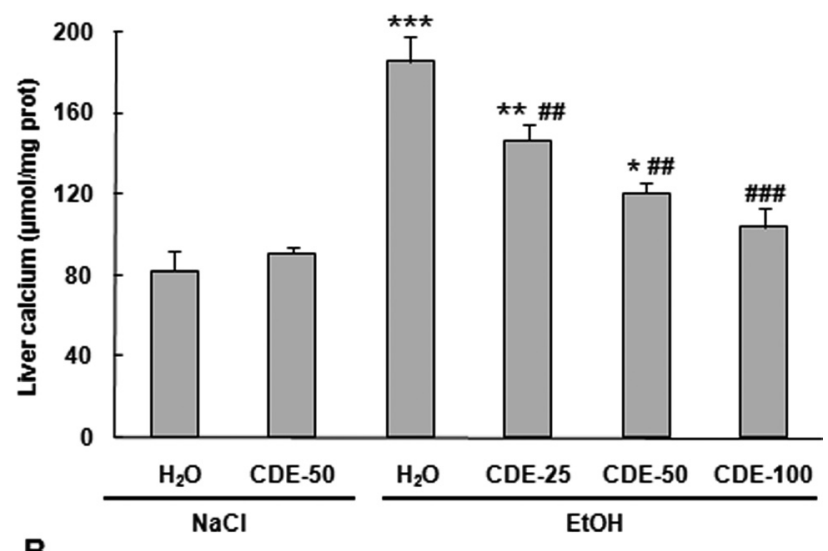

B

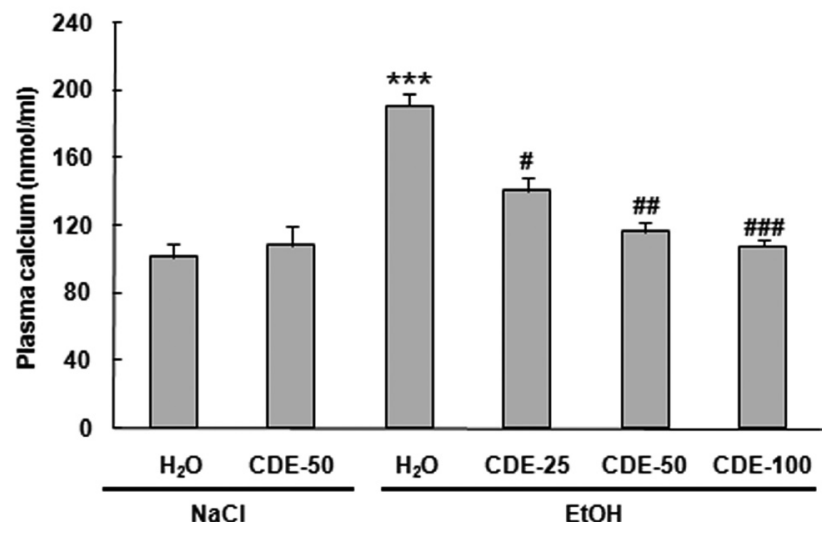

Figure 10. Subacute effect of $\mathrm{CDE}$ on acute $\mathrm{EtOH}$-induced changes in liver (A) and plasma (B) calcium level. Animals were pre-treated during 10 days with CDE and intoxicated by a single oral administration of for 2 hours $(n=10) .{ }^{*} p<0.05,{ }^{* *} p<0.01,{ }^{* * *} p<0.001$ compared to control group; ${ }^{\#} p<0.05,{ }^{\# \#} p<0.01,{ }^{\# \#} p<0.001$ compared to EtOH group. $\mathrm{CDE}$, chamomile decoction extract. 
oxidative stress through mechanisms associated with EtOH metabolism that generates reactive oxygen species (Owumi et al. 2012). However, ROS produced by cellular metabolic activities, and the alcohol-inducible enzymes can reduce cellular antioxidant defense capacity resulting in oxidative stress (Dey and Cederbaum 2006). Alcohol-induced tissue oxidative stress was widely documented in the liver (Dey and Cederbaum 2006; Nencini et al. 2010; Zhao et al. 2010), kidney, heart and brain (Zloch 1994; Kannan et al. 2004; Ibrahim et al. 2012).

More importantly CDE pre-treatment protected against EtOH-induced hepatic oxidative stress. These data fully corroborated all previously reported in vivo (HernándezCeruelos et al. 2010; Bulgari et al. 2012) and in vitro (Bhaskaran et al. 2012) antioxidant and anti-inflammatory properties of chamomille. EtOH-induced oxidative stress and liver dysfunction have been shown to be attenuated by curcumin (Nanji et al. 2003), resveratrol (Kasdallah-Grissa et al. 2007), N-stearoylethanolamine (Hula et al. 2010), folic acid (Lee et al. 2011), apocynin (Fan et al. 2012) and carob (Souli et al. 2013).

The in vivo antioxidant properties of CDE can also be resulting from the presence of phenolic compounds. These molecules are the primal source of the antioxidant ability of this plant, by scavenging free radicals as hydroxyl radical $\left(\mathrm{OH}^{\bullet}\right)$ which is the major cause of lipid peroxidation (Kogiannou et al. 2013).

We next sought to determine the putative involvement of intracellular mediators in EtOH and CDE mode of action. As expected, alcohol treatment increased $\mathrm{H}_{2} \mathrm{O}_{2}$, free iron and calcium levels in plasma and liver tissue. However, alcohol-induced liver iron increase was well documented in many previous studies (Houze et al. 1991; Conde-Martel et al. 1992; Shahbazian et al. 1994; Gonzalez-Reimers et al. 1996). Iron plays a central role in many of the ethanol intoxication-associated pathologies such as cardiovascular (Alpert 2004), neurodegenerative (Castellani et al. 2007) and hepatocellular injury (Uchiyama et al. 2008). Furthermore, both iron deficiency and iron excess can lead to cellular dysfunction, maintaining normal iron homeostasis is therefore crucial (Andrews 1999). Powell (1975) demonstrated that iron and $\mathrm{H}_{2} \mathrm{O}_{2}$ accumulation in ALD catalyzed the highly toxic hydroxyl radical $\left(\mathrm{OH}^{*}\right)$ production via the Fenton reaction leading to hepatocyte membranes lipoperoxidation and enhancement of its permeability to calcium. Indeed, it is well documented that deregulation of calcium homeostasis leading to its overload may have a major role in liver injury after alcohol consumption (Xiao et al. 2005 and González et al. 2008). Importantly, we showed in the present work that subacute pre-treatment with CDE protected against all EtOH-induced intracellular mediators disturbances. Our results also suggest that $\mathrm{CDE}$ exerts its beneficial effect by chelating free iron and scavenging $\mathrm{H}_{2} \mathrm{O}_{2}$ leading to calcium homeostasis as recently described by Hamlaoui-Gasmi et al. (2011). Further experiments are needed to assess the effect of chamomile extract on hepcidin, an iron shuttling protein, known for its implication in the pathogenesis of iron overload (Papanikolaou et al. 2005).

\section{Conclusion}

In conclusion, our data clearly demonstrate that CDE exerts protective effects against acute ethanol-induced injury in the rat liver owing to its antioxidant properties.

Acknowledgements. Financial support of the Tunisian Ministry of Higher Education and Scientific Research is gratefully acknowledged.

Declaration of interest. The authors declare no conflicts of interest.

\section{References}

Aebi H. (1984): Catalase in vitro. Methods Enzymol. 105, $121-126$ http://dx.doi.org/10.1016/S0076-6879(84)05016-3

Albano E. (2008): Oxidative mechanisms in the pathogenesis of alcoholic liver disease. Mol. Aspects Med. 29, 9-16 http://dx.doi.org/10.1016/j.mam.2007.09.004

Alpert P. T. (2004): New and emerging theories of cardiovascular disease: infection and elevated iron. Biol. Res. Nurs. 6, 3-10 http://dx.doi.org/10.1177/1099800404264777

Andrews N. C. (1999): Disorders of iron metabolism. N. Engl. J. Med. 341, 1986-1995

http://dx.doi.org/10.1056/NEJM199912233412607

Bhaskaran N., Shukla S., Kanwal R., Srivastava J. K., Gupta S. (2012): Induction of heme oxygenase- 1 by chamomile protects murine macrophages against oxidative stress. Life Sci. 90, 1027-1033 http://dx.doi.org/10.1016/j.lfs.2012.05.019

Bulgari M., Sangiovanni E., Colombo E., Maschi O., Caruso D., Bosisio E., Dell'Agli M. (2012): Inhibition of neutrophil elastase and metalloprotease- 9 of human adenocarcinoma gastric cells by chamomile (Matricaria recutita L.) infusion. Phytother. Res. 26, 1817-1822 http://dx.doi.org/10.1002/ptr.4657

Castellani R. J., Moreira P. I., Liu G., Dobson J., Perry G., Smith M. A., Zhu X. (2007): Iron: the Redox-active center of oxidative stress in Alzheimer disease. Neurochem. Res. 32, 1640-1645 http://dx.doi.org/10.1007/s11064-007-9360-7

Ceccanti M., Attili A., Balducci G., Attili, F., Giacomelli S., Rotond C., Sasso G. F., Xirouchakis E., Attilia M. L. (2006): Acute alcoholic hepatitis. J. Clin. Gastroenterol. 40, 833-841 http://dx.doi.org/10.1097/01.mcg.0000225570.04773.5d

Chandrashekhar V. M., Halagali K. S., Nidavani R. B., Shalavadi M. H., Biradar B. S., Biswas D., Muchchandi I. S. (2011): Antiallergic activity of German chamomile (Matricaria recutita L.) in mast cell mediated allergy model. J. Ethnopharmacol. 137, 336-340 
http://dx.doi.org/10.1016/j.jep.2011.05.029

Chon S. U., Heo B. U., Park Y. S., Kim D. K., Gorinstein S. (2009): Total phenolics level, antioxidant activities and cytotoxicity of young sprouts of some traditional Korean salad plants. Plant Foods Hum. Nutr. 64, 25-31 http://dx.doi.org/10.1007/s11130-008-0092-x

Clifford M. N., Wu W., Kirkpatrick J., Kuhnert N. (2007): Profiling the chlorogenic acids and other caffeic acid derivatives of herbal chrysanthemum by LC-MSn. J. Agric. Food Chem. 55, 929-936 http://dx.doi.org/10.1021/jf062314x

Conde-Martel A., González-Reimers E., Santolaria-Fernández F., Castro-Alemán V., Galindo-Martín L., Rodríguez-Moreno F., Martínez-Riera A. (1992): Combined effects of ethanol and protein deficiency on hepatic iron, zinc, manganese, and copper contents. Alcohol 9, 341-348

http://dx.doi.org/10.1016/0741-8329(92)90030-E

Dey A., Cederbaum A. I. (2006): Alcohol and oxidative liver injury. Hepatology 43, 63-74.

http://dx.doi.org/10.1002/hep.20957

Dingeon B., Ferry J. P., Roullet A. (1975): Automatic assay of blood sugar by Trinder's method. Ann. Biol. Clin. (Paris) 33, 3-13

Djeridane A., Yousfi M., Nadjemi B., Boutassouna D., Stocker P., Vidal N. (2006): Antioxidant activity of some algerian medicinal plants extracts containing phenolic compounds. Food Chem. 97, 654-660 http://dx.doi.org/10.1016/j.foodchem.2005.04.028

Donohue T. M. Jr., Osna N. A., Trambly C. S., Whitaker N. P., Thomes P. G., Todero S. L., Davis J. S. (2012): Early growth response-1 contributes to steatosis development after acute ethanol administration. Alcohol. Clin. Exp. Res. 36, 759v-767 http://dx.doi.org/10.1111/j.1530-0277.2011.01681.x

Draper H. H., Hadley M. (1990): Malondialdehyde determination as index of lipid peroxidation. Methods Enzymol. 186, 421-431 http://dx.doi.org/10.1016/0076-6879(90)86135-I

Ellman G. L. (1959): Tissue sulfhydryl groups. Arch. Biochem. Biophys. 82, 70-77 http://dx.doi.org/10.1016/0003-9861(59)90090-6

Fan R., Shan X., Qian H., Song C., Wu G., Chen Y., Miao, Y., Cha W. (2012): Protective effect of apocynin in an established alcoholic steatohepatitis rat model. Immunopharm. Immunotox. 34, 633-638 http://dx.doi.org/10.3109/08923973.2011.648266

Flohé L., Günzler W. A. (1984): Assays of glutathione peroxidase. Methods Enzymol. 105, 114-121 http://dx.doi.org/10.1016/S0076-6879(84)05015-1

González A., Pariente J. A., Salido G. M. (2008): Ethanol impairs calcium homeostasis following CCK-8 stimulation in mouse pancreatic acinar cells. Alcohol. 42, 565-573 http://dx.doi.org/10.1016/j.alcohol.2008.06.005

González-Reimers E., Santolaria-Fernández F., Perez-Labajos J., Rodríguez-Moreno F., Martinez-Riera A., Hernández-Torres O., Valladares-Parrilla F., Molina-Perez M. (1996): Relative and combined effects of propylthiouracil, ethanol and protein deficiency on liver histology and hepatic iron, zinc, manganese and copper contents. Alcohol Alcohol. 31, 535-545 http://dx.doi.org/10.1093/oxfordjournals.alcalc.a008189
Grzegorczyk I., Matkowski A., Wysokinska H. (2007): Antioxidant activity of extracts from in vitro cultures of Salvia officinalis L. Food Chem. 104, 536-541

http://dx.doi.org/10.1016/j.foodchem.2006.12.003

Guimarães R., Barros L., Due-as M., Calhelha R. C., Carvalho A. M., Santos-Buelga C., Queiroz M. J., Ferreira I. C. (2013): Infusion and decoction of wild German chamomile: bioactivity and characterization of organic acids and phenolic compounds. Food Chem. 136, 947-954 http://dx.doi.org/10.1016/j.foodchem.2012.09.007

Hamad İ., Erol-Dayi Ö., Pekmez M., Önay-Uçar E., Arda N. (2010): Antioxidant and cytotoxic activities of Aphanes arvensis extracts. Plant Foods Hum. Nutr. 65, 44-49 http://dx.doi.org/10.1007/s11130-009-0151-y

Hamlaoui-Gasmi S., Mokni M., Limam N., Limam F., Amri M., Aouani E., Marzouki L. (2011): Grape seed extract mitigates garlic-induced oxidative stress in rat spleen and plasma. J. Med. Plants Res. 5, 6076-6084

Hartree E. F. (1972): Determination of protein: a modification of the Lowry method that gives a linear photometric response. Anal. Biochem. 48, 422-427 http://dx.doi.org/10.1016/0003-2697(72)90094-2

Haseeb N., John S., Gauri S. M., Yukio K. (2006): Extraction of polyphenols from grape seeds and concentration by ultrafiltration. Sep. Purif. Technol. 48, 176-181

http://dx.doi.org/10.1016/j.seppur.2005.07.006

Hernández-Ceruelos A., Madrigal-Santillán E., Morales-González J. A., Chamorro-Cevallos G., Cassani-Galindo M., MadrigalBujaidar E. (2010): Antigenotoxic effect of Chamomilla recutita L. Rauschert essential oil in mouse spermatogonial cells, and determination of its antioxidant capacity in vitro. Int. J. Mol. Sci. 11, 3793-3802 http://dx.doi.org/10.3390/ijms11103793

Houze P., Rouach H., Gentil M., Orfanelli M. T., Nordmann R. (1991): Effect of allopurinol on the hepatic and cerebellar iron, selenium, zinc and copper status following acute ethanol administration to rats. Free Radic. Res. Commun. 2, 663-668 http://dx.doi.org/10.3109/10715769109145844

Hula N. M., Horid'ko T. M., Stohniǐ N. A., Klimashevs'kyǐ V. M., Mehed' O. F., Kosiakova H. V., Shovkun S. A., Kindruk N. L., Berdyshev A. H. (2010): Protective effect of N-stearoylethanolamine in acute alcohol intoxication in rats. Ukr. Biokhim. Zh. 82, 42-52 (in Ukrainian)

Ibrahim M., Hassan W., Meinerz D. F., Leite Gde O., Nogueira C. W., Rocha J. B. (2012): Ethanol-induced oxidative stress: the role of binaphthyl diselenide as a potent antioxidant. Biol. Trace Elem. Res. 147, 309-314 http://dx.doi.org/10.1007/s12011-012-9327-7

Kannan M., Wang L., Kang Y. J. (2004): Myocardial oxidative stress and toxicity induced by acute ethanol exposure in mice. Exp. Biol. Med. (Maywood) 229, 553-559

Kasdallah-Grissa A., Mornagui B., Aouani E., Hammami M., El May M., Gharbi N., Kamoun A., El-Fazaâ S. (2007): Resveratrol, a red wine polyphenol, attenuates ethanol-induced oxidative stress in rat liver. Life Sci. 80, 1033-1039 http://dx.doi.org/10.1016/j.lfs.2006.11.044

Kogiannou D. A., Kalogeropoulos N., Kefalas P., Polissiou M. G., Kaliora A. C. (2013): Herbal infusions; their phenolic profile, 
antioxidant and anti-inflammatory effects in HT29 and PC3 cells. Food Chem. Toxicol. 61, 152-159

http://dx.doi.org/10.1016/j.fct.2013.05.027

Lai J. P., Lim Y. H., Su J., Shen H. M., Ong C. N. (2007): Identification and characterization of major flavonoids and caffeoylquinic acids in three Compositae plants by LC/DAD-APCI/MS. J. Chromatogr. B Analyt. Technol. Biomed. Life Sci. 848, 215-225 http://dx.doi.org/10.1016/j.jchromb.2006.10.028

Leardi A., Caraglia M., Selleri C., Pepe S., Pizzi C., Notaro R., Fabbrocini A., De Lorenzo S., Musicò M., Abbruzzese A., Bianco A. R., Tagliaferri P. (1998): Desferioxamine increases iron depletion and apoptosis induced by ara-C of human myeloid leukaemic cells. Br. J. Haematol. 102, 746-752 http://dx.doi.org/10.1046/j.1365-2141.1998.00834.x

Lee S. J., Kang M. H., Min H. (2011): Folic acid supplementation reduces oxidative stress and hepatic toxicity in rats treated chronically with ethanol. Nutr. Res. Pract. 5, 520-526 http://dx.doi.org/10.4162/nrp.2011.5.6.520

Li G., Keyl P. M., Smith G. S., Baker S. P. (1997): Alcohol and injury severity: reappraisal of the continuing controversy. J. Trauma 42, 562-569 http://dx.doi.org/10.1097/00005373-199703000-00032

Lin L. Z., Harnly J. M. (2010): Identification of the phenolic components of chrysanthemum flower (Chrysanthemum morifolium Ramat). Food Chemistry 120, 319-326 http://dx.doi.org/10.1016/j.foodchem.2009.09.083

Maddrey W. C. (2000): Alcohol-induced liver disease. Clin. Liver Dis. 4, 115-131 http://dx.doi.org/10.1016/S1089-3261(05)70099-4

Matić I. Z., Juranić Z., Savikin K., Zdunić, G., Nađvinsk N., Gođevac D. (2013): Chamomile and marigold tea: chemical characterization and evaluation of anticancer activity. Phytother. Res. 27, 852-858 http://dx.doi.org/10.1002/ptr.4807

McKay D. L., Blumberg J. B. (2006): A review of the bioactivity and potential health benefits of chamomile tea (Matricaria recutita L.). Phytother. Res. 20, 519-530 http://dx.doi.org/10.1002/ptr.1900

Misra H. P., Fridovich I. (1972): The role of superoxide anion in autoxidation of epinephrine and a simple assay for superoxide dismutase. J. Biol. Chem. 247, 3170-3175

Nanji A. A., Jokelainen K., Tipoe G. L., Rahemtulla A., Thomas P., Dannenberg A. J. (2003): Curcumin prevents alcohol-induced liver disease in rats by inhibiting the expression of NF-kappa B-dependent genes. Am. J. Physiol. Gastrointest. Liver Physiol. 284, 321-327

http://dx.doi.org/10.1152/ajpgi.00230.2002

Nencini C., Franchi G. G., Cavallo F., Michel L. (2010): Protective effect of Allium neapolitanum Cyr. versus Allium sativum L. on acute ethanol-induced oxidative stress in rat liver. J. Med. Food 13, 329-335 http://dx.doi.org/10.1089/jmf.2008.0180

Nordmann R. (1994): Alcohol and antioxidant systems. Alcohol Alcohol. 29, 513-522

Owumi S. E., Odunola O. A., Aliyu M. (2012): Co-administration of sodium arsenite and ethanol: Protection by aqueous extract of Aframomum longiscapum seeds. Pharmacognosy Res. 4, 154-160 http://dx.doi.org/10.4103/0974-8490.99078

Ozaras R., Tahan V., Aydin S., Uzun H., Kaya S., Senturk H. (2003): $\mathrm{N}$-acetylcysteine attenuates alcohol-induced oxidative stess in rats. World J. Gastroenterol. 9, 791-794

Papagiannopoulos M., Wollseifen H. R., Mellenthin A., Haber B., Galensa R. (2004): Identification and quantification of polyphenols in carob fruits (Ceratonia siliqua L.) and derived products by HPLC-UV-ESI/MSn. J. Agric. Food Chem. 52, 3784-3791 http://dx.doi.org/10.1021/jf030660y

Papanikolaou G., Tzilianos M., Christakis J. I., Bogdanos D., Tsimirika K., MacFarlane J., Goldberg Y. P., Sakellaropoulos N., Ganz T., Nemeth E. (2005): Hepcidin in iron overload disorders. Blood 105, 4103-4105

http://dx.doi.org/10.1182/blood-2004-12-4844

Parveen I., Threadgill M. D., Hauck B., Donnison I., Winters A. (2011): Isolation, identification and quantitation of hydroxycinnamic acid conjugates, potential platform chemicals, in the leaves and stems of Miscanthus $\times$ giganteus using LC-ESI-MSn. Phytochemistry 72, 2376-2384

http://dx.doi.org/10.1016/j.phytochem.2011.08.015

Powell L. W. (1975): The role of alcoholism in hepatic iron storage disease. Ann. N. Y. Acad. Sci. 252, 124-134 http://dx.doi.org/10.1111/j.1749-6632.1975.tb19149.x

Price M. L., Van-Scovo S., Buttler L. G. (1978): A critical evaluation of the Vanillin reaction as an assay for tannin in sorghum grain. J. Agr. Food Chem. 26, 1214-1218 http://dx.doi.org/10.1021/jf60219a031

Ranpariya V. L., Parmar S. K., Sheth N. R., Chandrashekhar V. M. (2011): Neuroprotective activity of Matricaria recutita against fluoride-induced stress in rats. Pharm. Biol. 49, 696-701 http://dx.doi.org/10.3109/13880209.2010.540249

Rehm J., Room R., Graham K., Monteiro M., Gmel G., Sempos C. T. (2003): The relationship of average volume of alcohol consumption and patterns of drinking to burden of disease: an overview. Addiction 98, 1209-1228 http://dx.doi.org/10.1046/j.1360-0443.2003.00467.x

Salamon I. (1992): Chamomile, a medicinal plant. The Herb, Spice, and Medicinal Plant Digest. 10, 1-4

Samuhasaneeto S., Thong-Ngam D., Kulaputana O., Suyasunanont D., Klaikeaw N. (2009): Curcumin decreased oxidative stress, inhibited NF-kappaB activation, and improved liver pathology in ethanol-induced liver injury in rats. J. Biomed. Biotechnol. 2009, 981963

http://dx.doi.org/10.1155/2009/981963

Sebai H., Jabri M. A., Souli A., Rtibi K., Selmi S., Tebourbi O., El-Benna J., Sakly M. (2014): Antidiarrheal and antioxidant activities of Chamomile (Matricaria recutita L.) decoction extract in rats. J. Ethnopharmacol. 152, 327-332 http://dx.doi.org/10.1016/j.jep.2014.01.015

Sebai H., Souli A., Chehimi L., Rtibi K., Amri M., El-Benna J., Sakly M. (2013): In vitro and in vivo antioxidant properties of Tunisian carob (Ceratonia siliqua L.). J. Med. Plants Res. 7, 85-90

Shahbazian L. M., Wood S., Watson R. R. (1994): Ethanol consumption and early murine retrovirus infection influence liver, heart, and muscle levels of iron, zinc, and copper in C57BL/6 mice. Alcohol Clin. Exp. Res. 18, 964-968 http://dx.doi.org/10.1111/j.1530-0277.1994.tb00067.x 
Sharafzadeh S., Alizadeh O. (2011): German and Roman Chamomile. Journal of Applied Pharmaceutical Science 1, 1-5

Silva N. C., Barbosa L., Seito L. N., Fernandes A. Jr. (2012): Antimicrobial activity and phytochemical analysis of crude extracts and essential oils from medicinal plants. Nat. Prod. Res. 26, 1510-1514 http://dx.doi.org/10.1080/14786419.2011.564582

Souli A., Sebai H., Chehimi L., Rtibi K., Tounsi H., Boubaker S., Sakly M., El-Benna J., Amri M. (2013): Hepatoprotective effect of carob against acute ethanol-induced oxidative stress in rat. Toxicol. Ind. Health (in press) http://dx.doi.org/10.1177/0748233713475506

Stern J., Lewis W. H. (1957): The colorimetric estimation of calcium in serum with ocresolphthalein complexone. Clin. Chim. Acta 2, 576-580 http://dx.doi.org/10.1016/0009-8981(57)90063-3

Uchiyama A., Kim J. S., Kon K., Jaeschke H., Ikejima K., Watanabe S., Lemasters J. J. (2008): Translocation of iron from lysosomes into mitochondria is a key event during oxidative stressinduced hepatocellular injury. Hepatology 48, 1644-1654 http://dx.doi.org/10.1002/hep.22498

Xiao Z. M., Li L. J., Yu S. Z., Lu Z. N., Li C. Y., Zheng J. Q. (2005): Effects of extracellular $\mathrm{Ca}(2+)$ influx and intracellular $\mathrm{Ca}(2+)$ release on ethanol-induced cytoplasmic $\mathrm{Ca}(2+)$ overload in cultured superior cervical ganglion neurons. Neurosci. Lett. 390, 98-103 http://dx.doi.org/10.1016/j.neulet.2005.08.004
Yang L., Wu D., Wan X., Cederbaum A. I. (2012): Cytochrome P4502E1, oxidative stress, JNK, and autophagy in acute alcoholinduced fatty liver. Free Radic. Biol. Med. 53, 1170-1180 http://dx.doi.org/10.1016/j.freeradbiomed.2012.06.029

Zhao M., Du Y.Q., Yuan L., Wang N. N. (2010): Protective effect of puerarin on acute alcoholic liver injury. Am. J. Chin. Med. 38, 241-249 http://dx.doi.org/10.1142/S0192415X10007816

Zhong Z., Froh M., Lehnert M., Schoonhoven R., Yang L., Lind H., Lemasters J. J. (2003): Thurman RG. Polyphenols from Camellia sinenesis attenuate experimental cholestasis-induced liver fibrosis in rats. Am. J. Physiol. Gastrointest. Liver Physiol. 285, 1004-1013 http://dx.doi.org/10.1152/ajpgi.00008.2003

Zhou Z., Wang L., Song Z., Lambert J. C., McClain C. J., Kang Y. J. (2003): A critical involvement of oxidative stress in acute alcohol-induced hepatic TNF-alpha production. Am. J. Pathol. 163, 1137-1146 http://dx.doi.org/10.1016/S0002-9440(10)63473-6

Zloch Z. (1994): Temporal changes of the lipid peroxidation in rats after acute intoxication by ethanol. Z. Naturforsch C. 49, 359-36

Received: May 6, 2014

Final version accepted: October 21, 2014

First published online: March 27, 2015 